\title{
The immobilization of DNA molecules to electrodes in confined channels at physiological pH
}

\author{
V R Dukkipati and S W Pang ${ }^{1}$ \\ Department of Electrical Engineering and Computer Science, The University of Michigan, \\ Ann Arbor, MI 48109-2122, USA \\ E-mail: pang@umich.edu
}

Received 31 January 2008, in final form 31 July 2008

Published 21 October 2008

Online at stacks.iop.org/Nano/19/465102

\begin{abstract}
Large numbers of DNA molecules are immobilized to electrodes at the physiological $\mathrm{pH}$ of 8.0, and the length of the immobilized DNA molecules is controlled using an ac voltage. Efficient DNA immobilization at physiological $\mathrm{pH}$ has been demonstrated by integrating electrodes in confined channels $500 \mathrm{~nm}$ wide and $100 \mathrm{~nm}$ deep. The low volume of the channels allows large numbers of DNA molecules to access the electrode surfaces, leading to efficient immobilization.
\end{abstract}

(Some figures in this article are in colour only in the electronic version)

\section{Introduction}

Single-molecule DNA analysis has been used to study DNAprotein interactions [1]. The control of DNA immobilization and stretching is critical for these studies [2], in which DNA molecules are often immobilized at one end and stretched to different lengths to study the effect of the stretched length on the enzyme kinetics [3]. Immobilization of large numbers of DNA molecules on substrates [4] and electrodes [5] has been shown in buffer solutions with $\mathrm{pH}$ ranging from 5.5 to 6.6 [6]. Immobilization is typically not performed at a $\mathrm{pH}$ of 8.0 , since fewer DNA molecules can be immobilized [6]. However, the rate of catalysis, which is an indicator of the efficiency of enzymatic actions, is maximum for most enzymes near the physiological $\mathrm{pH}$ of 8.0 [7]. Although immobilization has been demonstrated at $\mathrm{pH} 8.0$ by the formation of a DNA-protein complex, as DNA molecules are stretched by fluid flow in a microchannel, this technique does not allow precise placement of the DNA molecules [8]. In addition, using the shear flow of a fluid, control of the DNA stretched length is not possible since the shear force acting on the DNA molecule varies during stretching [9].

In order to overcome the limitation of inefficient DNA immobilization at $\mathrm{pH} 8.0$, a second buffer around physiological $\mathrm{pH}$ is often introduced to perform protein interactions

\footnotetext{
1 Author to whom any correspondence should be addressed.
}

following DNA immobilization at lower $\mathrm{pH}$ [10]. However, the two buffer solutions may react with one another and alter the protein interactions. Therefore, there is a need to develop a system which can controllably immobilize and stretch DNA molecules using only one buffer solution at $\mathrm{pH}$ 8.0. Here, we utilize confinement in shallow channels to increase the immobilization efficiency of DNA molecules to electrodes at physiological $\mathrm{pH}$. Confined channels provide unique advantages that are often used in DNA mapping [11] and biomolecular separations [12]. We have designed and fabricated fluidic systems integrated with electrodes, which provide close proximity of the DNA molecules to the electrodes made possible by shallow channels, to control the DNA stretching at physiological $\mathrm{pH}$. Such a system can be used for single-molecule DNA-protein interaction studies.

In this study, we have demonstrated the immobilization and stretching of DNA molecules across electrodes integrated in $500 \mathrm{~nm}$ wide and $100 \mathrm{~nm}$ deep channels. The DNA molecules are introduced through an inlet port into the low volume channels, where they remain to be stretched due to entropy confinement. We have also shown that DNA immobilization onto electrodes at $\mathrm{pH} 8.0$ is greatly enhanced in the smaller channels compared to channels that are wider and deeper, demonstrating that the channel dimensions have a strong influence on the immobilization efficiency. Additionally, the DNA stretched length is controlled by varying the ac voltage applied across the electrodes. 


\section{Integration of electrodes in channels}

The fabrication technology to integrate electrodes with sealed channels is based on bonding an array of $\mathrm{Si}$ channels with electrodes on a thin glass substrate using PMMA as an adhesive layer [13]. PMMA bonding is used to integrate electrodes with the channel array since PMMA does not clog the channels during bonding due to its high viscosity. 20/50 nm thick $\mathrm{Cr} / \mathrm{Au}$ electrodes were patterned on a $100 \mu \mathrm{m}$ thick glass substrate. 6\% $950 \mathrm{~K}$ PMMA in anisole solvent was spin-coated on the glass with patterned electrodes to a thickness of $600 \mathrm{~nm}$. A Ti layer was evaporated and patterned on the PMMA to define areas over which the PMMA is etched. The etched PMMA exposes the electrodes to fluid in the channels. The direct contact between the electrodes and the fluid containing the DNA molecules allows the electric field to have strong influence on the DNA molecules near to and as far away as $>1 \mathrm{~mm}$ from the electrodes.

Si channels having two different sizes were fabricated in order to compare the immobilization efficiency in the channels. The $100 \mu \mathrm{m}$ wide channel was patterned using contact lithography, followed by dry etching to a depth of $20 \mu \mathrm{m}$ using reactive ion etching in $\mathrm{SF}_{6}$ and $\mathrm{C}_{2} \mathrm{~F}_{6}$. The $500 \mathrm{~nm}$ wide $\mathrm{Si}$ channels were patterned using projection lithography, followed by dry etching in a $\mathrm{Cl}_{2}$ plasma. Fluidic ports of $300 \mu \mathrm{m}$ in diameter were etched through the entire Si substrate using a deep reactive ion etching process. The Si substrate with the etched channels and fluidic ports was cleaned in 1:1 $\mathrm{H}_{2} \mathrm{O}_{2}: \mathrm{H}_{2} \mathrm{SO}_{4}$ before bonding. The $\mathrm{Si}$ surface was oxidized during the clean, resulting in hydrophilic $\mathrm{Si}$ channels, which allow the DNA molecules to flow in the channels by capillary action [14]. The bonding of the glass wafer containing the $\mathrm{Cr} / \mathrm{Au}$ electrodes to the $\mathrm{Si}$ substrate with various channels was performed at $110^{\circ} \mathrm{C}$, above the glass transition temperature of PMMA $\left(109^{\circ} \mathrm{C}\right)$, for $15 \mathrm{~min}$ at a pressure of $0.4 \mathrm{MPa}$.

Figure 1 shows an array of $500 \mathrm{~nm}$ wide and $100 \mathrm{~nm}$ deep $\mathrm{Si}$ channels integrated with $\mathrm{Cr} / \mathrm{Au}$ electrodes. The region without PMMA exposes the electrodes to the buffer and DNA molecules in the channels, allowing control of the DNA immobilization and stretching using the voltage applied across the electrode gap. Since the PMMA around the electrodes has been removed, the channel region close to the electrodes has a gap of $600 \mathrm{~nm}$, while the channel regions away from the electrode are still covered with PMMA. Similar fluidic systems with $100 \mu \mathrm{m}$ wide channels were also fabricated.

To clarify the design of the fluidic system with the integrated electrodes, figure 2 shows the schematics of the top view and cross-sectional views along the two orientations of the Si channels. The size of the glass substrate is larger than the Si chip in order to access the electrical contacts by connecting to the electrodes present on the glass substrate. The etched PMMA region exposes the electrodes to the DNAcontaining fluid in the channels, while the rest of the Si chip is sealed to the glass substrate through a PMMA bonding layer, as shown in the cross-sectional views of figure 2 . The channels are $4 \mathrm{~mm}$ long and they are connected to two $300 \mu \mathrm{m}$ diameter inlet/outlet ports. The fluidic channels under the etched PMMA are shown in the cross-section B-B'. An

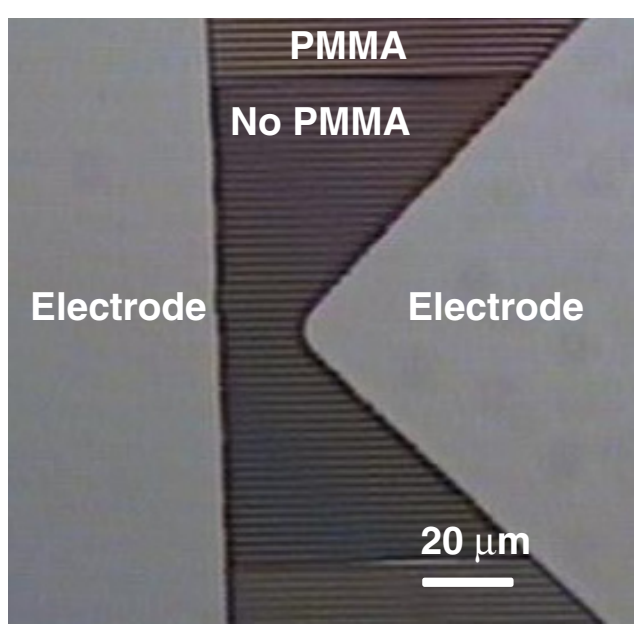

Figure 1. 20/50 nm thick $\mathrm{Cr} / \mathrm{Au}$ electrodes on glass integrated with $500 \mathrm{~nm}$ wide, $100 \mathrm{~nm}$ deep Si channels using PMMA bonding. The area without PMMA exposes the electrodes to DNA molecules in the fluidic channels.

array of multiple channels has the advantage of providing simultaneous observation of multiple units in a single system.

\section{Stretching of DNA molecules in confined channels}

Partially stretched DNA molecules are obtained in the confined channels. As shown in figure 3, the channels are sealed with a glass using PMMA as an adhesive layer. T2 DNA molecules at $5 \mathrm{pM}$ concentration in tris-ethylenediaminetetraacetic acid (TRIS-EDTA) buffer ( $\left.1 \mathrm{mM}, \mathrm{pH}=8.0, \sigma=150 \mu \mathrm{S} \mathrm{cm}^{-1}\right)$ were introduced at the inlet port of a $150 \mu \mathrm{m}$ wide and $1 \mu \mathrm{m}$ deep channel which is connected to an array of $500 \mathrm{~nm}$ wide and $100 \mathrm{~nm}$ deep channels. The $150 \mu \mathrm{m}$ wide channel allows DNA molecules to be partially stretched before they enter the $500 \mathrm{~nm}$ wide channel array, enabling a large number of DNA molecules to flow into the narrower channel. The DNA molecules flow into the channels by the capillary action and they are subsequently pumped by the fluid evaporation from the outlet port. The flow is stopped by filling the outlet port with the same buffer solution to equalize the pressure at the ports. Figure 3 shows stationary T2 DNA molecules in an array of $500 \mathrm{~nm}$ wide channels. The same channels were integrated with electrodes to perform the efficient immobilization of DNA molecules described in the next section. The DNA molecules are partially stretched due to the volume confinement of the $500 \mathrm{~nm}$ wide channels. Molecules of different length are present in the channels since the molecules are partially coiled at the steady state and are undergoing continuous fluctuations. The DNA molecules can be stretched to greater lengths and they can be stabilized by introducing them into channels with smaller cross-sectional area. They can also be stretched by applying an electric field or hydrodynamic flow.

\section{Immobilization of DNA molecules to electrodes at physiological pH}

DNA molecules were immobilized to the integrated electrodes at one end, followed by stretching the DNA molecules across 


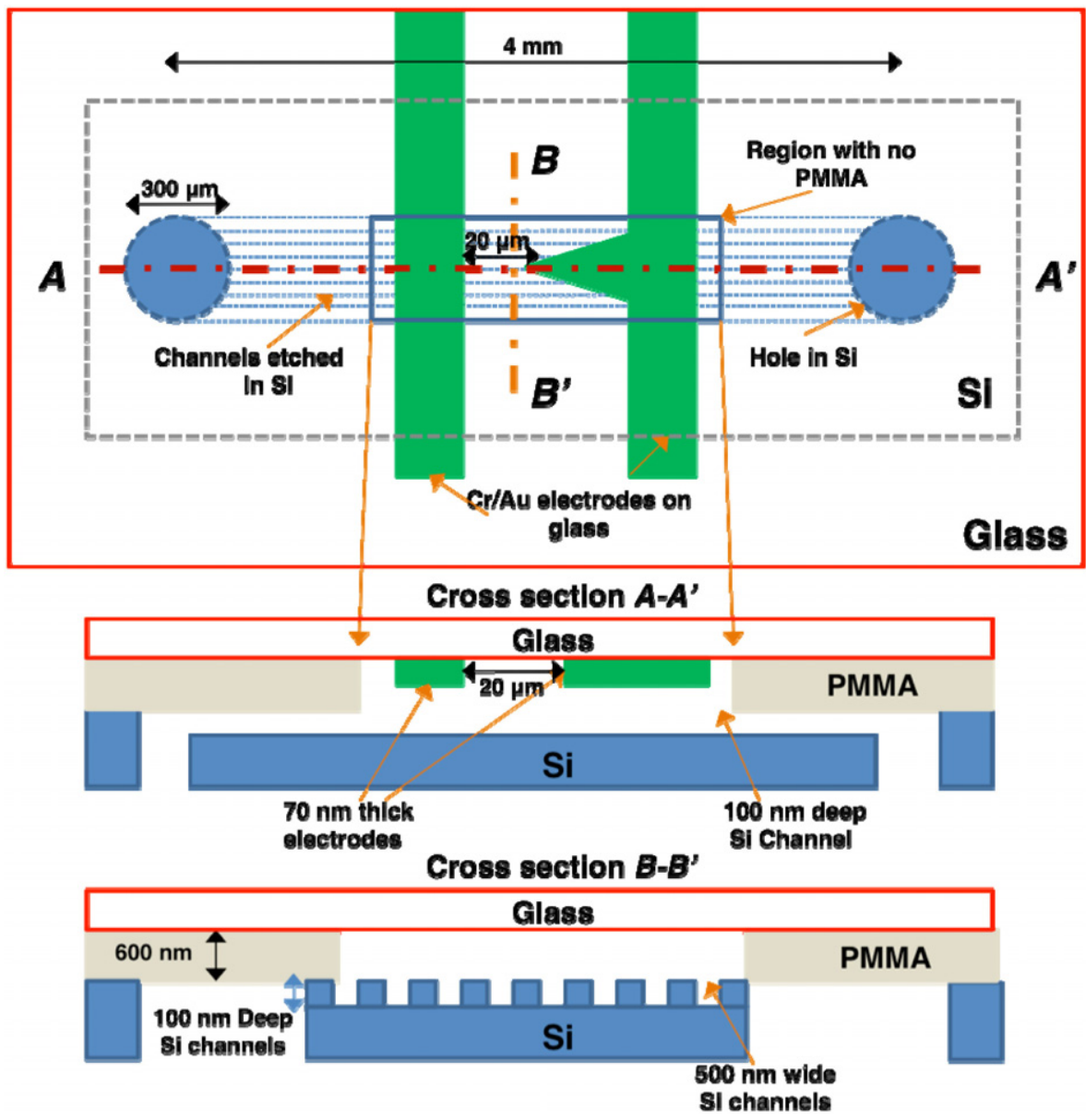

Figure 2. Schematic drawings showing the top view and cross-sectional views of Si channels with integrated electrodes. The fluidic system confines DNA molecules in low volume.

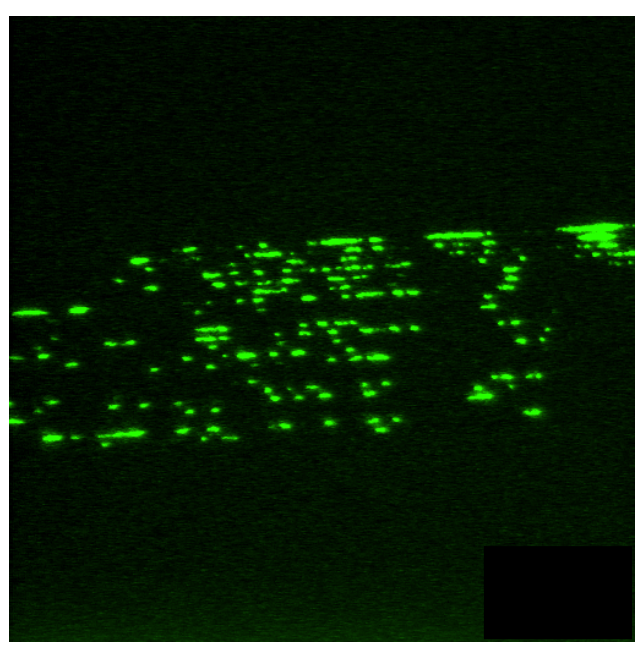

Figure 3. Partially stretched T2 DNA molecules in $500 \mathrm{~nm}$ wide and $100 \mathrm{~nm}$ deep channels. The flow of DNA molecules is stopped and DNA molecules are stationary in channels.

the electrode gap. The number of DNA molecules that are immobilized and stretched was compared at acidic and physiological $\mathrm{pH}$ in two different fluidic systems. The DNA molecules were immobilized and stretched across the electrode gap using an ac voltage applied across the gap, which exerts a number of forces on free and immobilized DNA molecules present in the electrode gap. The forces influencing DNA immobilization and stretching are described below.

There are three forces that influence the DNA molecules present in the electrode gap. The first is the dielectrophoretic force, which is caused by the induced dipole along the backbone of the DNA molecules [15]. This force is directed towards the electrode edges. The second force is the torque exerted on the induced dipole by the electric field. For a DNA molecule with one end immobilized on the electrode, the torque tends to elongate the DNA molecule parallel to the electric field [16]. The third force is the electrothermal force acting on the fluid [17]. This force is generated by the gradients in conductivity and permittivity of the fluid due to the field-induced fluidic heating. When an ac field is applied between two electrodes in a fluidic system, each electrode induces a circulatory fluidic motion across the electrodes. These two circulating fluids in the electrode gap prevent the immobilized DNA molecules from stretching beyond the range of the corresponding circulating fluid [18]. The field-induced torque and the direction of the electrothermal-force-induced fluid flow result in the DNA stretching. The direction of the fluid flow depends on several factors, such as the electric field and temperature gradient [19]. In order for the attached DNA 


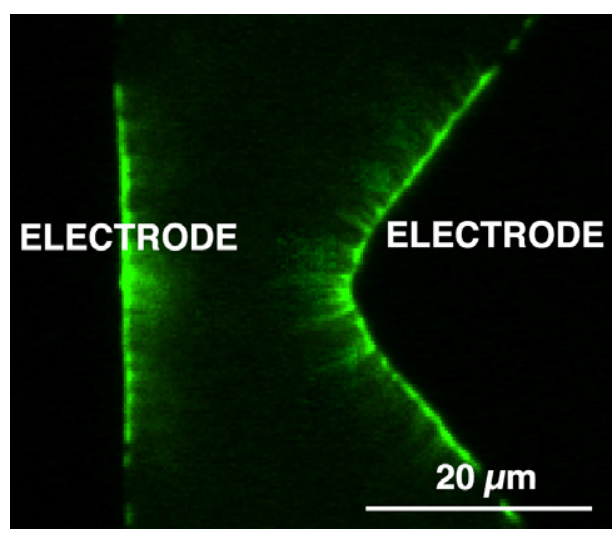

(a)

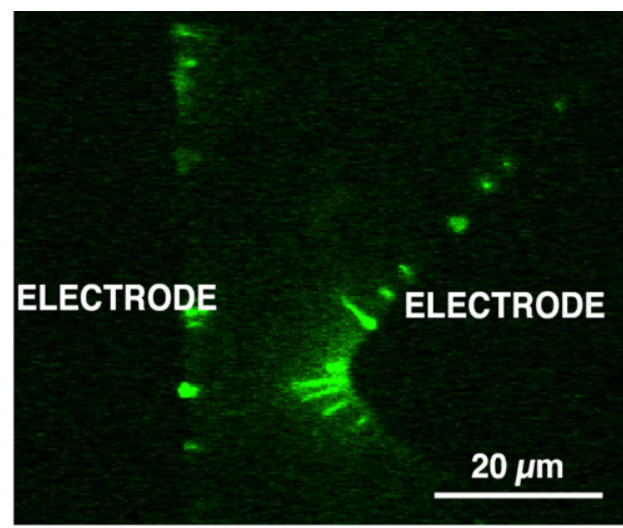

(b)

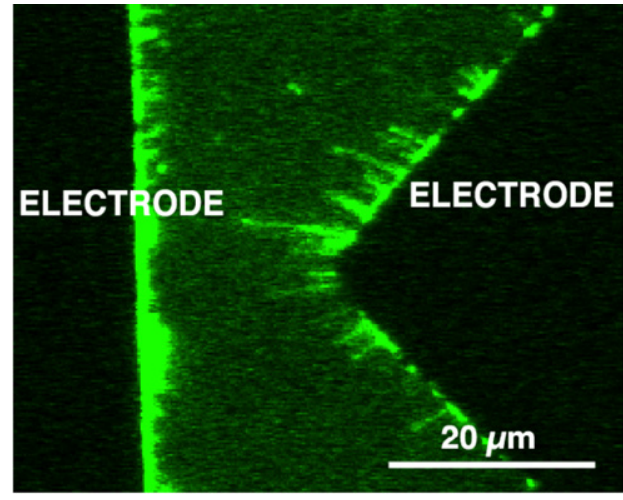

(c)

Figure 4. Immobilized and stretched $\lambda$-DNA molecules in a $100 \mu \mathrm{m}$ wide and $20 \mu \mathrm{m}$ deep channel with (a) MES buffer at $\mathrm{pH} 5.8$,

(b) TRIS-EDTA buffer at pH 8.0, and (c) with TRIS-EDTA buffer at $\mathrm{pH} 8.0$ in smaller channels $500 \mathrm{~nm}$ wide and $100 \mathrm{~nm}$ deep.

to stretch, the fluid has to flow from the edge of the electrode towards the electrode gap. The DNA stretched length depends only on the electric field and not on the field gradient since the torque which stretches the DNA molecules depends only on the electric field. The field gradient determines the direction of the electrothermal force, which affects the directionality of the stretched DNA.

DNA immobilization and stretching in a microchannel at acidic and physiological $\mathrm{pH}$ have been compared, and an increase in the number of DNA molecules immobilized to electrodes at physiological $\mathrm{pH}$ in confined channels was

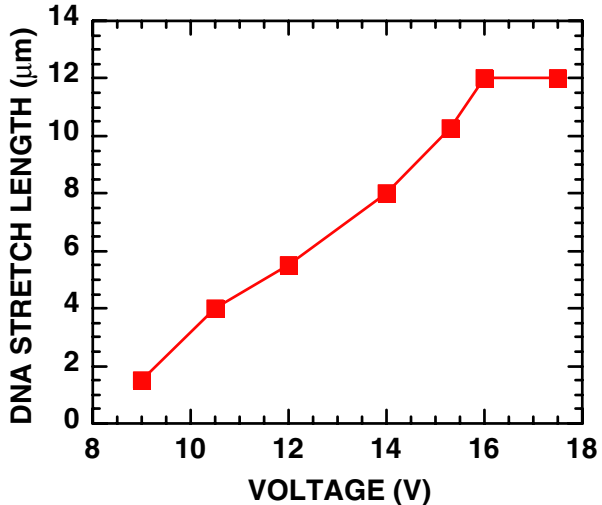

Figure 5. Variation of stretched lengths of $\lambda$-DNA molecule in TRIS-EDTA buffer as ac voltage is applied at $100 \mathrm{kHz}$.

found. $\lambda$-DNA molecules at $5 \mathrm{pM}$ concentration in 2morpholinoethanesulfonic acid (MES) $(25 \mathrm{mM}, \mathrm{pH}=5.8$, $\left.\sigma=370 \mu \mathrm{S} \mathrm{cm}^{-1}\right)$ and TRIS-EDTA $(1 \mathrm{mM}, \mathrm{pH}=8.0$, $\sigma=150 \mu \mathrm{S} \mathrm{cm}^{-1}$ ) buffer were introduced in two different fluidic systems. Similar results were obtained using T2 DNA molecules. The DNA molecules were labeled with YOYO1 fluorescent dye with a dye to base ratio of 1:10. The buffer with DNA molecules was pumped into the channel from the inlet port by capillary force. The DNA molecules were brought to rest in the channels before applying voltage by hydrating the outlet port with the same buffer solution. A $100 \mathrm{kHz}$ ac field was applied across the electrodes, which was slowly ramped up from 1 to $20 \mathrm{~V}$. The electrothermal-force-induced flow moves the DNA molecules towards the electrodes, which results in some of the DNA molecules being immobilized on the electrodes. Beyond $8 \mathrm{~V}$, the immobilized DNA molecules begin to stretch and the stretched length increases with applied voltage. Figures 4(a)-(c) show $\lambda$-DNA molecules immobilized and stretched at $16 \mathrm{~V}$ in fluidic systems at two different $\mathrm{pH}$ conditions. Figures 4(a) and (b) show the comparison of DNA molecules immobilized to electrodes at $\mathrm{pH} 5.8$ and 8.0, respectively, in a $100 \mu \mathrm{m}$ wide and $20 \mu \mathrm{m}$ deep channel. The number of DNA molecules immobilized to the electrodes at $\mathrm{pH} 8.0$ is less compared to the number at $\mathrm{pH} 5.8$.

To improve the DNA immobilization efficiency at $\mathrm{pH}$ 8.0, channels with smaller dimensions were used to provide better confinement. Figure 4(c) shows a larger number of $\lambda$-DNA molecules immobilized and stretched at $16 \mathrm{~V}$ in $500 \mathrm{~nm}$ wide and $100 \mathrm{~nm}$ deep channels in TRIS-EDTA buffer with $\mathrm{pH}$ 8.0. The smaller channels improve DNA immobilization to the electrodes due to the greater possibility of DNA molecules being in contact with the electrode surface compared to $100 \mu \mathrm{m}$ wide and $20 \mu \mathrm{m}$ deep channels.

Figure 5 shows the variation of DNA stretched length with voltage in confined channels at $\mathrm{pH}$ 8.0. The stretched length is determined as the maximum length from the edge of the electrode to the end of the stretched DNA molecules. The pointed electrode on the right-hand side provides higher electric field near the tip; therefore the stretched length of the DNA is longer near the electrode tip. Similar voltage dependence of DNA immobilization and stretching has been obtained in electrodes with straight edges rather than pointed 
tips. DNA molecules are attached at different positions from the edge of the electrode, and DNA molecules with different stretched lengths are observed in figures 4(a)-(c) at a given voltage. The electrothermal flow drives the DNA molecules towards the electrode surface, which results in the DNA molecules contacting the electrode surface and becoming immobilized near the electrode edges. After immobilization, the DNA strands begin to align and stretch along the electric field lines, and the stretched length increases with voltage. A maximum stretched length of $12 \mu \mathrm{m}$ is obtained for DNA molecules stretched from the pointed electrode tip. The contour length (theoretical maximum length) of $\lambda$-DNA molecules is $16.5 \mu \mathrm{m}$. The difference between the measured maximum stretched length and the contour length is due to the immobilization of one end of a DNA molecule at a finite distance from the edge of the electrode. These results demonstrate the capability to control the electricfield-dependent stretched length of DNA molecules using appropriate ac voltage and electrode design.

\section{Summary}

Control over DNA immobilization in low volume channels with integrated electrodes is demonstrated. $\mathrm{Cr} / \mathrm{Au}$ electrodes are integrated with $500 \mathrm{~nm}$ wide and $100 \mathrm{~nm}$ deep $\mathrm{Si}$ channels. Immobilization and stretching of larger number of DNA molecules on the electrodes across an electrode gap is achieved at a physiological $\mathrm{pH}$ of 8.0 in confined channels by applying an ac voltage. The DNA stretched length is controlled by varying the voltage applied across the electrode gap. The ability to immobilize and stretch a large number of DNA molecules at physiological $\mathrm{pH}$ in confined channels is important for the development of single-molecule DNA studies.

\section{Acknowledgments}

The authors would like to acknowledge the technical assistance from K Sung and J H Kim. This project is supported by the National Science Foundation under grant No. NSF-NIRT 0304316 .

\section{References}

[1] Ichiro A, Ronald J B and Stephen C K 2006 Visualization of Rad54, a chromatin remodeling protein, translocating on single DNA molecules Mol. Cell. 23 143-8
[2] Bustamante C, Bryant Z and Smith S B 2003 Ten years of tension: single-molecule DNA mechanics Nature 421 423-7

[3] Gemmen G J, Millin R and Smith D E 2006 Tension-dependent DNA cleavage by restriction endonucleases: two-site enzymes are switched off at low force Proc. Natl Acad. Sci. USA 103 11555-60

[4] Bensimon A, Simon A, Chiffaudel A, Croquette V, Heslot F and Bensimon D 1994 Alignment and sensitive detection of DNA by a moving interface Science 265 2096-8

[5] Dukkipati V R and Pang S W 2007 Precise DNA placement and stretching in electrode gaps using electric fields in a microfluidic system Appl. Phys. Lett. 90083901

[6] Allemand J F, Bensimon D, Jullien L, Bensimon A and Croquette V $1997 \mathrm{pH}$-dependent specific binding and combing of DNA Biophys. J. 73 2064-70

[7] Stanford N P, Halford S E and Baldwin G S 1999 DNA cleavage by the EcoRV restriction enzyme endonuclease: $\mathrm{pH}$ dependence and proton transfers in catalysis J. Mol. Biol. 288 105-16

[8] Dukkipati V R, Kim J H, Pang S W and Larson R G 2006 Protein-assisted stretching and immobilization of DNA molecules in a microchannel Nano Lett. 6 2499-504

[9] Smith D E, Babcock H P and Chu S 1999 Single-molecule dynamics in steady shear flow Science 283 1724-7

[10] Gueroui Z, Place C, Freyssingeas E and Berge B 2002 Observation by fluorescence microscopy of transcription on single combed DNA molecules Proc. Natl Acad. Sci. USA $996005-10$

[11] Riehn R, Lu M, Wang Y, Lim S F, Cox E C and Austin R H 2005 Restriction mapping in nanofluidic devices Proc. Natl Acad. Sci. USA 102 10012-6

[12] Yuan Z, Garcia A L, Lopez G P and Petsev D N 2007 Electrokinetic transport and separations in fluidic nanochannels Electrophoresis 28 595-610

[13] Dukkipati V R and Pang S W 2007 Integration of electrodes in Si channels using low temperature polymethylmethacrylate bonding J. Vac. Sci. Technol. B 25 368-72

[14] Yang L J, Yao T J and Tai Y C 2004 The marching velocity of the capillary meniscus in a microchannel J. Micromech. Microeng. 14 220-5

[15] Germishuizen W A, Walti C, Wirtz R, Johnston B M, Pepper M, Davies A G and Middelberg A P J 2003 Selective dielectrophoresis manipulation of surface-immobilized DNA molecules Nanotechnology 14 896-902

[16] Cohen A E 2003 Force-extension curves of a polymer in a high-frequency electric field Phys. Rev. Lett. 91235506

[17] Ramos A, Morgan H, Green N G and Costellanos A 1998 AC electrokinetics: a review of forces in microelectrode structures J. Phys. D: Appl. Phys. 31 2338-53

[18] Walti C, Tosch P, Davies A G, Germishuizen W A and Kaminski C F 2006 Establishment of the ac electrokinetic elongation mechanism of DNA by three-dimensional fluorescent imaging Appl. Phys. Lett. 88153901

[19] Chen D F and Du J H 2006 Simulation studies on electrothermal fluid induced in a dielectrophoretic microelectrode system J. Micromech. Microeng. 16 2411-9 